\title{
Research
}

\section{Towards Adaptive Management: Examining the Strategies of Policy Entrepreneurs in Dutch Water Management}

\author{
Stijn Brouwer $^{1}$ and $\underline{\text { Frank Biermann }}^{1}$
}

\begin{abstract}
The growing awareness of the complexities and uncertainties in water management has put into question the existing paradigms in this field. Increasingly more flexible, integrated, and adaptive policies are promoted. In this context, the understanding of how to effect policy change is becoming more important. This article analyzes policy making at the micro level, focusing on the behavior of policy entrepreneurs, which we understand here as risk-taking bureaucrats who seek to change policy and are involved throughout the policy-change process. Policy entrepreneurs have received a certain level of attention in the adaptive co-management literature and the policy sciences in past decades. Yet, the understanding of the actions they can take to facilitate policy change remains limited. This study addresses this gap in focusing on the strategies that policy entrepreneurs employ in their efforts to effect policy change. The article draws on both theoretical exploration and in-depth field research on water management in the Netherlands, which included a series of semi-structured interviews and a focus group with policy entrepreneurs. We conclude that policy entrepreneurs employ four types of strategies: (1) attention and support-seeking strategies, to demonstrate the significance of a problem and to convince a wide range of participants about their preferred policy; (2) linking strategies, to link with other parties, projects, ideas, and policy games; (3) relational management strategies, to manage the relational factor in policy-change trajectories; and finally, (4) arena strategies, to influence the time and place wherein decisions are made. Our study suggests that by employing these strategies when the "time is right," the development of policy streams and consequently their coupling can, to some extent, be influenced and steered. In other words, policy entrepreneurs can, to a degree, prepare for a window of opportunity and hence direct policy change.
\end{abstract}

Key Words: adaptive management; policy change; policy entrepreneurs; strategies; water management; windows of opportunity

\section{INTRODUCTION}

The capability to adapt to and direct change is an important element of resilience in social-ecological systems (Gunderson 1999, Folke et al. 2005) as well as of strategies of earth system governance (Biermann 2007). Scholars of the adaptive comanagement literature argue against traditional management approaches that aim at optimal use and control of resources. Instead, the management of social-ecological systems should be continuously updating its goals, measures, and policies (Olsson et al. 2004, Hahn et al. 2006, Plummer and Armitage 2007). The overall goal of adaptive management is less about maintaining an optimal condition of a resource and more about building up management capacity to cope with change and unpredictability. To achieve that, managers should view their actions and policies as experiments and involve and collaborate with stakeholders. This allows the system to react and its managers to respond to changing conditions (Walters and Holling 1990, Johnson 1999). Adaptive co-management combines the strengths of this approach with the link characteristic of collaborative management (Armitage et al. 2007).

These insights are highly relevant in the area of water management. Here, a growing awareness of the complexities and uncertainties has generated critical consideration of existing water management paradigms, and it has promoted more flexible and adaptive strategies. Among others, it has been suggested that a transition is under way to "soft path" managerial and governance solutions to ecological problems that complement the previously favored "hard path" physical infrastructure (Gleick 2003). Accordingly, the capability to direct change will be important in any water management system. We aim to deepen understanding of the way in which change can be directed.

Various authors (see, e.g., Ostrom 1965, Kuhnert 2001, Olsson et al. 2006) have argued that the role of individual actors is essential in shaping change to achieve the flexibility needed to deal with ecosystem dynamics. The important role of individuals in advancing policy change has also been emphasized at the level of international policies, for example, in comprehensive studies on the influence of the lead executive officers of international organizations (Biermann and Siebenhüner 2009). Since the early 1980s, this topic has received attention from various policy scientists (see, e.g., Kingdon 1984, King and Roberts 1987, Weissert 1991, Baumgartner and Jones 1993), who have shown that there is room for individual actors to help stimulate or redirect debate about policy issues. Building and synthesizing upon this work, scholars have given increasing attention to policy entrepreneurs (see, e.g., Young 1991, Schiller 1995, Schneider et al. 1995, Mintrom and Vergari 1996, 1998, Mintrom 2000). Yet, there remain important gaps in our knowledge. Apart from studies by Roberts and King (1991) and Huitema and 
Meijerink (2009a, 2010), analyses of what policy entrepreneurs actually do have been rather general. None of the existing studies systematically specifies the actions that policy entrepreneurs take at the subnational, regional level, where most practical projects are carried out.

Our effort is thus mainly intended to analyze the actions of policy entrepreneurs at the subnational, regional project level. The main research question is "What strategies can policy entrepreneurs employ in their efforts to pursue policy change?" We have organized this article in four sections. The first section introduces the literature on policy entrepreneurs and distinguishes them from other actors in policy making. The second section elaborates on the research design and introduces the context of the study. The third section identifies and classifies strategies of policy entrepreneurs, drawing on an extensive theoretical exploration, a series of in-depth interviews, and a focus group with policy entrepreneurs in Dutch water management. The final section reflects on the actions of policy entrepreneurs and what they imply for understanding policy change.

\section{POLICY ENTREPRENEURS}

Initially, "entrepreneur" basically meant "businessman." The French economist Say first coined the term in 1800, defining an entrepreneur as a person who "shifts economic resources out of an area of lower and into an area of higher productivity and greater yield" (see Drucker 1985). Since the work of Schumpeter in the 1930s, the term is mostly identified with innovation (Stevenson and Jarillo 1990). Gradually, scholars have expanded the use of the idea of entrepreneurship and adapted the concept from business to the public sector (deLeon 1996). Kingdon (1984:129), one of the first scholars to apply the term entrepreneurs to the public sector, defines policy entrepreneurs as "advocates for proposals or for the prominence of ideas." During the past decade, policy entrepreneurs have increasingly become recognized as important political actors. Mintrom (1997, 2000; Mintrom and Vergari 1998), in particular, has done much to advance our knowledge.

We understand policy entrepreneurs to be risk-taking bureaucrats who seek to change policy and are involved throughout the policy-change process. This definition is, among others, grounded in the work of Kingdon (1984) and Mintrom (2000), who both maintain that the exact position of policy entrepreneurs in the policy-making process is unimportant. We concur with these authors in that policy entrepreneurs are primarily identifiable by the actions they take, rather than by the positions they hold. Yet, here, we restrict the use of the term policy entrepreneurs to members of regional bureaucracies in the area of water management. Policy entrepreneurs are, much as in the case of business entrepreneurs, on the alert for opportunities. Policy entrepreneurs see chances to connect policy proposals (solutions) to problems and participants (to political momentum). One could argue that everyone involved in policy making now and then sees policy gaps and contributes in some sense to policy change. This does not, however, make them policy entrepreneurs. We distinguish policy entrepreneurs from policy intellectuals, who are only engaged in the generation of innovative ideas; from knowledge brokers, who provide links between different knowledge sources; and from policy advocates, who mainly translate ideas into proposals. In this study, policy entrepreneurs are instead understood as actors who are involved throughout the policy-change process. In addition, policy entrepreneurs differ from other participants in policy making in their above-average willingness to take risks and accept failure.

\section{RESEARCH DESIGN}

The case study informing our analysis on the actions of policy entrepreneurs is the water management system in the Netherlands. Dutch water management is highly consensusbased, complex, and fragmented. It can be defined as a multilevel governance system with a relatively high degree of decentralization. Decision making is based on close collaboration between the central government and authorities at the regional (provinces and water boards) and local levels (municipalities) (Kuks 2010, Van Leussen and Lulofs 2010). Although there is a myriad of interesting developments in Dutch water management that could be discussed, we intend first and foremost to explain the actions of policy entrepreneurs. Therefore, the policy changes in Dutch water management only represent the case through which to examine our actual unit of analysis-the individual policy entrepreneur.

We have chosen the Netherlands as a case because of its rich and diverse institutional context in local and regional water management. Furthermore, it represents an outstanding example of a social-ecological system wherein through the ages the flow and level of almost every water body has been subject to human control (Kuks 2010). Given the new needs to anticipate on (expected) climate change effects, such as increasing river run-off and sea-level rise, in combination with the continuous subsidence of soil, and the spatial claims of housing, industry, infrastructure, and agriculture, Dutch water projects require not only technical solutions (e.g., raising dikes) but also complex spatial solutions, such as reserving land for a floodplain (Roth and Warner 2007, Huitema and Meijerink 2009b). As a consequence, rather than working alone as they did in the past, Dutch water managers now often need resources and support from a wide range of organizations, policy programs, and policy domains and therefore must look beyond their particular program and deal with greater levels of coordinated action and strategic play (Van der Brugge et al. 2005). In short, the problems facing Dutch water managers have become increasingly, and fundamentally, more complex: both the management of the system and the governing 
processes are in transition. This implies that many policy changes in water management are needed, which makes the country a highly interesting place to study the role and actions of policy entrepreneurs. Table 1 provides two examples of the types of projects with which policy entrepreneurs are typically involved.

Table 1. Project examples.

Example 1: The Waterdunen project: In this innovative project in the southwest portion of the Netherlands, an improvement of the coastal defense is turned into a quality-improvement opportunity of the nature, landscape, and recreation. It consists of the realization of 250 hectares salty nature that is influenced by a controlled tide. Waterdunen is a special plan with a number of innovations, including a nontraditional form of cooperation, at which public parties, private parties, and nongovernmental organizations work together on the basis of equality.

Example 2: The Breakthrough project: In this extensive project in the eastern portion of the Netherlands, a new 13-km-long brook is created to separate the rural and urban water flow, aiming at improving surface water quality. In addition, this new waterway will provide an extra drainage possibility for excessive water, ensuring that the safety of a sizable area will be improved. Finally, the construction of the brook is a powerful stimulus for the ecology and recreation.

To develop systematic ideas on these actions of policy entrepreneurs, we conducted both theoretical and empirical studies that encompassed the following steps:

(1) First, we studied theoretical models in fields as diverse as political science, public administration, network management, and project management for assumptions and findings regarding strategies that policy entrepreneurs can employ in their efforts to pursue policy change. Based on this theoretical study, we developed a set of strategies.

(2) To investigate whether this set was applicable and to investigate whether and how policy entrepreneurs actually use these and/or other strategies, we conducted 10 semistructured, in-depth interviews with policy entrepreneurs in Dutch water management in two rounds. The first round of interviews was open and explorative but was structured around two primary topics: the entrepreneurs' background, ambition, and work context, and the step-by-step description of two individual projects and the strategic decisions concerned. In the second round of interviews, we confronted the same policy entrepreneurs with statements on strategies and strategic dilemmas based on the results of the first round. All interviews were conducted in Dutch, yet we reproduced a small sample of our interview questions (see Appendix 1), with the rest being available on request.
(3) To provide depth and detail on some of the topics discussed in the first and second rounds of the interviews, we then organized a focus group in which all but two of the interviewed policy entrepreneurs participated. In addition, we conducted an additional 15 interviews with experts in the field of policy change in and around water boards (including members of the board, consultants, and representatives from municipalities and provinces).

The policy entrepreneurs included in our study had been selected by stratified sampling. In each geographically based stratum, we randomly selected one water board in which a key informant was identified to determine the most prominent policy entrepreneur within the organization. The experts in the field of policy change in and around water boards for the additional interviews were selected after a workshop on water management where our primary results were presented. To maximize an atmosphere of openness and trust, all face-toface interviews were conducted at the work place of the interviewee and strict anonymity was guaranteed. It is worth noting that we found that policy entrepreneurs are not necessary always aware of their strategic behavior. Only in the course of the highly open and explorative interviews did they become conscious of the many actions and strategic choices they actually continuously employed in the highly complex policy-change processes in which they are involved. The next section contains the combined results of the theoretical study on strategies along with the results of our empirical research and an analysis on whether and how policy entrepreneurs in Dutch water management employ these and/ or other strategies.

\section{ENTREPRENEURIAL STRATEGIES}

We found various strategies that policy entrepreneurs employ in their efforts to pursue policy change. We inductively established that this abundance of strategies- can be grouped into four categories: (1) attention- and support-seeking strategies, to demonstrate the significance of a problem and to convince a wide range of participants about their preferred policy; (2) linking strategies, to link with other parties in coalitions, projects, ideas, and policy games; (3) relational management strategies, to manage the relational factor in policy change trajectories; and, finally, (4) arena strategies, to influence the time and the place wherein policy entrepreneurs act. Table 2 presents an overview of the four categories and the subsumed strategies.

\section{Attention- and support-seeking strategies}

The ultimate goal of a policy entrepreneur is to achieve policy change. Accordingly, an alternative idea or approach is a prerequisite (Huitema and Meijerink 2010). Yet, rather than the talent to develop new ideas, in this study on the subnational, regional project level, we rather see the alertness for opportunities to connect existing ideas to problems and participants (to political momentum) as a key characteristic of 
successful policy entrepreneurs. In fact, most of the time, people reformulate (old) ideas-coming from a plethora of different sources-and combine them with others (Kingdon 1984, Mintrom 2000). Accordingly, we focus on the strategies that policy entrepreneurs employ after they have seen an opportunity for policy change and try to "sell" their preferred idea. Thus, although we do not exclude the possibility that policy entrepreneurs are at times involved in developing new ideas, we do not consider this a strategy of individual policy entrepreneurs (unlike Huitema and Meijerink 2010). Instead, we are more interested in the process of what happens after policy entrepreneurs see an opportunity and what they actually do in their effort to convince a wide range of individuals, groups, and organizations of their preferred idea. The range of strategies that policy entrepreneurs employ to "sell" their ideas we call attention- and support-seeking strategies. We identify five different attention- and support-seeking strategies: the use of pilot projects, the demonstration of indicators, the highlighting of focusing events, rhetoric persuasion, and correlating.

Table 2. Strategies of policy entrepreneurs used in Dutch water management.

\begin{tabular}{llll}
\hline \hline $\begin{array}{l}\text { Attention- and } \\
\text { support- } \\
\text { seeking } \\
\text { strategies }\end{array}$ & $\begin{array}{l}\text { Linking } \\
\text { strategies }\end{array}$ & $\begin{array}{l}\text { Relational } \\
\text { management } \\
\text { strategies }\end{array}$ & $\begin{array}{l}\text { Arena } \\
\text { strategies }\end{array}$ \\
\hline & & & \\
- Pilot projects & $\bullet$ Coalition & $\bullet$ Trust & $\bullet$ Venue \\
- Indicators & building & building & shopping \\
- Focusing & $\bullet$ Selective & $\bullet$ Networking & $\bullet$ Timing \\
events & activation and & & \\
- Rhetoric & exclusion & & \\
persuasion & $\bullet$ Issue linking \\
- Correlating & $\bullet$ Game linking & & \\
& & &
\end{tabular}

Demonstration of pilot projects, indicators, and focusing events

The literature provides ample hypotheses about the selection processes by which new ideas and policy proposals are chosen (see, e.g., Koppenjan 1993, Mintrom 2000). Important strategies to draw attention to new ideas are the use of smallscale pilot projects (Huitema and Meijerink 2009a) as well as indicators and expert testimony (Kingdon 1984). Several scholars, such as Cohen et al. (1972) and Kingdon (1984), focus also on the relation of problem and solution. An important element in their models is the understanding that, in addition to problems in search of solutions, solutions might also float around searching for problems. Accordingly, we expect that, in their efforts to gain attention and support for a new idea, policy entrepreneurs will also aim to demonstrate the magnitude of a problem. To this end, we expect that policy entrepreneurs will again use indicators and, more important, highlight focusing events like crises or disasters (Kingdon 1984, Birkland 1988, Westley 2002, Ingram and Fraser 2006).

In our empirical research, we found indeed that policy entrepreneurs in Dutch water management consider indicators, expert testimony, and providing actual working examples as important means to draw attention to their advocated ideas. In addition, we found evidence in support of Kingdon (1984), Birkland (1988), Westley (2002), Ingram and Fraser (2006), and Huitema and Meijerink (2009a) that the policy entrepreneurs also in Dutch local water management now and then draw attention to focusing events like crises or disasters to exhibit the significance of a problem. As one policy entrepreneur put it, "Every now and then I wish for a small calamity. Such events garner political support for my ideas, be it on the condition that they are prepared in advance." In addition, we found that policy entrepreneurs in Dutch water management not only use indicators and expert testimony to gain support for their ideas but also to display the magnitude of a problem. As one Dutch policy entrepreneur interviewed for this study remarked, "High-quality reports with highquality appendices are needed, no blah blah stories ... you organize an information evening ... and at a certain point they will start believing you."

\section{Rhetoric persuasion and correlating}

How a particular problem is defined is of great importance as it shapes the direction in which possible solutions are sought. In addition, depending on the definition, some actors are involved whereas others are not, some are helped and others hurt (Kingdon 1984, Stone 1997). Also in demonstrating the importance and meaning of crises, or in displaying the success of a pilot project, the specific wording can greatly affect the likelihood of an innovation being introduced (Birkland 1988, Dutton and Ashford 1993, Fischhendler and Zilberman 2005). Therefore, we assume that rhetorical persuasion is an important strategy for policy entrepreneurs. By using rhetorical persuasion, policy entrepreneurs do not try to get preferred policy innovations to be adopted by changing the alternatives, but try to change preferences through arguing within existing dimensions of current policy discussions. It often implies that policy entrepreneurs adapt their way of speaking and decide which aspects of the problem or the solution they want to emphasize or downplay depending on the positions and preoccupations of different participants.

The importance of rhetorical persuasion is well supported by evidence from our study. Rhetorical persuasion appears to be very important in the entrepreneurs' efforts to draw attention and gain support for the problem they aim to solve and their advocated "solution." In fact, all policy entrepreneurs 
interviewed argued that the interpretation of a crisis or data really can transform conditions into problems. In addition, our interviews were rich with examples showing that policy entrepreneurs often adapt their way of speaking depending on the positions and preoccupations of different participants. For example, a policy entrepreneur explained, "When I aim to acquire a European subsidy, I emphasize the social, economic, and ecological problems in the area. But when I try to acquire a provincial subsidy for the very same project, I tell them how the project complements with their program." This finding is in coherence with the work of many scholars, including Birkland (1988) and Stone (1997). Finally, we found that, in the entrepreneurs' efforts to open up new policy opportunities, the role of problems is of at least equal importance to the role of ideas. Policy entrepreneurs do no stop with "simply" asking for attention to a problem and demonstrating their ideas. Instead, they work very hard to present their idea as a solution to the identified problem. The corresponding strategy, which we call the correlating strategy, might sound straightforward, yet is so far mostly neglected or at least underexposed in the literature.

\section{Linking strategies}

In theory, policy entrepreneurs pursuing policy change have the choice to realize their plans and ideas on their own or in collaboration. In practice, however, the scale (and levels) at which problems are experienced regularly do not correspond to the scale at which decision-making bodies operate. For this reason, policy entrepreneurs are mostly unable to accomplish their objectives alone and frequently seek collaboration and link with individuals and groups in a coalition. Aside from coalition building, policy entrepreneurs employ three other linking strategies: selective activation and exclusion, issue linking, and game linking.

\section{Coalition building, selective activation, and exclusion}

According to the literature, various individuals, groups, and organizations are often involved in a specific policy issue and/ or the necessary resources to accomplish the change, such as physical resources, juridical resources, money, knowledge, and support, are often divided over different individuals, groups, and organizations (Booher and Innes 2000, Koppenjan and Klijn 2004). Accordingly, we assume that policy entrepreneurs in Dutch water management frequently experience dependency on the actions or resources of others and collaborate with others. The degree to which collaboration is needed is based on various factors and will differ from situation to situation. To use the words of Dutton and Ashford (1993), the choice is not so much whether a coalition needs to be built, but rather what kind of coalition. Also in Huitema and Meijerink (2010), coalition building is defined as an important strategy.

Connected with coalition building is the strategy of selective activation and exclusion. Because the joining of forces generally entails sensitive issues, such as differences of policy objectives and power asymmetries, coalition building is often delicate (Huitema and Meijerink 2009a). Accordingly, we assume that policy entrepreneurs are liable to apply the selective activation strategy, that is, "assess which actors are essential at given moments in a policy process, whether and how to involve them" (Pahl-Wostl et al. 2006:26). This can also imply exclusion, that is, deliberatively leaving out actors (in particular stages) of a policy-making process. Some argue that policy making can be improved by activating more participants as they bring in new solutions and resources (Teisman 1990), whereas Mintzberg et al. (1996) state that more participants implies inevitably more complexity and more complicated negotiations.

In theory, policy entrepreneurs pursuing change have the choice to realize their plans and ideas on their own or in collaboration. In practice, it appears that policy change in Dutch water management can hardly be realized individually. This drives the building of coalitions. For this reason, and in line with the research of Mintrom $(1997,2000)$ and Huitema and Meijerink (2010), policy entrepreneurs in Dutch water management frequently seek collaboration and link with individuals and groups in coalitions: "Even for our own water retention projects it is impossible to say 'we can plan, organize and implement our ideas ourselves'; that is not the way it works." The most frequently, but not exclusively, noted motivation for coalition building was the acquisition of money and support. In addition, learning or knowledge generation is an important motivation for policy entrepreneurs to collaborate. As one policy entrepreneur noted, "Next year we are going to implement a fish stock policy so we involved the angler groups. They do not have any money, but they have knowledge." Then again, we found that policy entrepreneurs not always opt for large coalitions, let alone for processes of collaborative problem solving. Our in-depth empirical study of policy entrepreneurs in Dutch water management revealed that policy entrepreneurs indeed employ the strategy of selective activation and, at times, exclusion. This finding corroborates with the work of Pahl-Wostl et al. (2006). To be more precise, we found that policy entrepreneurs reflect deeply about not only when to involve which parties but also on the total number of participants in a coalition. Even though we observed that the policy entrepreneurs in Dutch water management operate in complex systems, they do not view all issues as highly complex and accordingly assess broad coalitions strategically. Other times, we found that policy entrepreneurs, in the view of the complexity of the issue itself, feel collaborative problem solving could be beneficial but still opt for small coalitions because actors might be unwilling to cooperate or because time or resources are lacking. The fear for complication and stagnation, however, is the most important motivation to avoid broad coalitions. This last argument, in particular, provides support for the work of 
Fischhendler (2004), Koppenjan and Klijn (2004), and Innes and Booher (2010). Our research suggests that policy entrepreneurs are generally very good in making appraisals as to when to involve which actors; nonetheless, we found that, from time to time, policy entrepreneurs face the dilemma of small versus broad coalitions. As one policy entrepreneur interviewed for this study remarked, "At times it is better to involve that specific party, other times it is not. It is a matter of tactics." Yet, the overall feeling of policy entrepreneurs in Dutch water management is that it is not strategic to exclude or deactivate parties: "The exclusion of parties is never a smart idea. You will always meet them again and this can frustrate your interest tremendously."

\section{Issue linking}

Based on the work of Mintrom (2000), we expected that policy entrepreneurs must also be prepared to adjust their preferred problem definition and ideas for policy change to the interests and expectations of other participants. Such strategy is known as issue linking. It entails the linking of two or more issues, both the addition of dimensions to a problem and the combination of solutions with other solutions, for substantive and/or strategic reasons. Issue linking may contribute to different approaches, richer debates, and more successful outcomes (Teisman 1990, de Bruijn and ten Heuvelhof 2000). Because different individuals, groups, or organizations involved in policy formation become co-responsible for decisions, issue linking might also lead to more social and political support. At the same time, it may be a mechanism to realign or break existing coalitions (Fischhendler and Zilberman 2005). Yet, because participants are more likely to defend their own interests, this strategy does not always pay off and may cause delays, stagnation, or even conflicts (Fischhendler 2004, Koppenjan and Klijn 2004, Meijerink 2008).

The importance of issue linking is well supported by evidence from our comprehensive study of Dutch policy entrepreneurs in the water management sector. In their efforts to realize their preferred policy change, policy entrepreneurs not only link with other actors and parties, but also link problems and solutions. We found that policy entrepreneurs repeatedly take different problem perceptions and interests into account aiming to develop and select a solution that is satisfying for all relevant participants. In line with Teisman (1990) and de Bruijn and ten Heuvelhof (2000), all interviewed entrepreneurs felt that issue linking, if launched at the right moment, increases the likelihood of a better solution: "If you realize with a number of parties multiple goals on the same unit of land/plot ... for the same, or perhaps less money, you can have a better plan." The strategy of issue linking is not exclusively employed for the good of the product but also for the process. As one policy entrepreneur remarked: "If you only try to reach your own goal ... at a certain point you run up against so many objections from other parties that you can not make progress anymore." Aside from the advantages of issue linking, policy entrepreneurs experienced the dangers in terms of complication and stagnation, similar to what we have seen related to coalition building. As a result, they often reported facing a "single multi-issue" dilemma: "At times, it is hard to say what is best. Linking generates high value-added projects, at the same time, however, it may also cause more complexity, delays, and less mandate."

\section{Game linking}

Policy change does not occur in a vacuum but in an arena with many ongoing policy games with partly overlapping issues and participants. Accordingly, efforts to change policy are influenced by other games, taking place at the same time or even in the future. Although this phenomenon may complicate efforts of realizing policy change, based on the work of Axelrod and Keohane (1985) and Putnam (1988), among others, we expect that policy entrepreneurs will also link games strategically. Game linking entails the linking of two or more parallel or future policy games, which opens up possibilities to find mutually acceptable concession packages.

In our study, we found that policy entrepreneurs in Dutch water management strategically link one or more games, and hence found support for the work of Axelrod and Keohane (1985) and Putnam (1988). A policy entrepreneur explained the choice to support a certain nonessential plan: "For [us] this plan is only negative, there is zero advantage ... Still, we support it as we hope that they will support us with our project in the future." This citation shows us that policy entrepreneurs indeed note that strategic moves at one game table might facilitate or obstruct coalitions at the second table, and why policy entrepreneurs are sometimes prepared to take loss. In connection with this strategy, we found that policy entrepreneurs frequently face the dilemma between holding on to a certain position versus giving it away with the aim to receive better rewards (compensation) in another (future) game. Given that the same participants frequently need each other in parallel or future policy games, policy entrepreneurs state that the rules of the game are often played in such a manner that relations are not deteriorated.

\section{Relational management strategies}

In policy games, policy entrepreneurs inevitably do not deal with abstract representatives from "the other side" but with human beings with emotions, values, and ideas. Consequently, the policy game always has two outcomes: one substantive and one relational. The human aspect can help enormously when relations are characterized by mutual trust, respect, or even friendship. At the same time, when people feel angry, offended, annoyed, or betrayed, negotiations can be very difficult (Fisher et al. 1983, Koppenjan and Klijn 2004). Accordingly, it makes sense for a policy entrepreneur to negotiate in a way that fosters future good relations and does 
not deteriorate them (Mintrom 2000, Koppenjan and Klijn 2004). Policy entrepreneurs use two main strategies: trust building and networking.

\section{Trust building}

The theoretical notion of the importance of relational management is supported by our study. We found that policy entrepreneurs in Dutch water management are very sensitive to the fact that they deal with human beings with emotions, values, and ideas. Hence, they stated that good relationships are crucial for the process of policy change: "Poor relationships can result in terrible delays; they make it very hard to reach your goals quickly." "When you reach your goal at the expense of your relationships, you will have to be very sure that you won't need that relation in the future. If you will need that relation in the future, you are certainly lost." Because most negotiations take place within existing relations, most interviewed policy entrepreneurs note that they always try to create or maintain good relations for the pursuit of their goals. In this regard, they state that it is important to display cooperative behavior and perhaps even more important to develop relationships of trust, and with that established evidence in support of the work of Kingdon (1984), Schneider et al. (1995), Mintrom (2000), Williams (2002), and Huitema and Meijerink (2010). At the same time, they confirmed how difficult and time consuming it is to build relationships of trust and how easy it is to lose it: "If at a certain point in time you can show that you keep your promise, you become a serious partner ... It is devastating if you make an agreement and can not honor it" ... "It only has to happen once and you have absolute distrust." What we expected less, however, is the critical importance of trust building. Yet, policy entrepreneurs in Dutch water management emphasized the importance of working toward good relations characterized by respect and mutual trust more than any other strategy. In this regard, it is interesting to note that, in the literature on adaptive comanagement and resilience, the importance of building trust actually is recognized (Olsson et al. 2004, Lebel et al. 2005, Hahn et al. 2006, Berkes 2009).

\section{Networking}

Given that policy entrepreneurs are mostly dependent on other parties, it can be expected that policy entrepreneurs will invest time and energy to build or maintain good relations by both formally and informally talking with and listening to a broad set of actors engaged in a certain domain, a strategy we refer to as networking. Networks matter because they help policy entrepreneurs to discover opportunities to build coalitions and gather reliable information in a relatively easy and efficient manner. Moreover, networking enables the entrepreneur to understand the preferences and worries of other participants (Kingdon 1984, Schneider et al. 1995, Mintrom 2000, Williams 2002). Indeed, also in Huitema and Meijerink's (2010) set of strategies, the strategy of the orchestration and managing of networks is prominently present. Research indicates that networks differ in nature; some networks can be long lasting, involving few interdependent actors frequently interacting, whereas others can be loosely integrated and relatively ad hoc. By definition, networks are always broader if compared with a coalition (Stevenson and Jarillo 1990). Important in this respect is the concept of redundancy: the key of networking is building relations not only with parties that are directly necessary, but also with those not directly needed in order to reach certain goals (de Bruijn and ten Heuvelhof 2000). Westley (2002) argues that cooperative behavior and networking is not only valid for external partners but also for within the internal organization.

This study indeed found that policy entrepreneurs in Dutch water management generally spend much time networking. As one policy entrepreneur put it: "I try to attend any meeting ... whether it is from the farmers or nature conservationists ... I am a member of all relevant organizations. Moreover, I keep up with what happens in the municipal councils, also on my evenings off." Hence, we established evidence in support of the work of Kingdon (1984), Schneider et al. (1995), Mintrom (2000), Williams (2002), and Huitema and Meijerink (2010). The entrepreneurs report that networks matter because they help them discover new ideas and opportunities. Networking enables them to understand the preferences, plans, worries, and world views of the other participants. This knowledge helps them to discover opportunities for coalition building, issue linking, and game linking. In addition, they state that networking helps them to determine which arguments will persuade others to support their policy ideas. As one Dutch policy entrepreneur interviewed for this study remarked, "I think it is important to see which way the wind blows by a wide range of people ... it is key to get a feeling about people's ideas."

As a final point, the policy entrepreneurs in our study emphasized that relational management is by no means solely an external concern. Instead, the present study revealed that policy entrepreneurs perceive networking within their internal organization as being at least as important as networking with external partners. They feel the game within their organization (support of the internal political board and bureaucratic organization) is as crucial as the external game. As one policy entrepreneur noted, "If you negotiate with partners about a project, perhaps the negotiation process back home is even more important." This finding is consistent with that of Westley (2002), yet the great importance that policy entrepreneurs attach to it is a new insight.

\section{Arena strategies}

Other than attention- and support-seeking strategies, linking strategies, and relational management strategies, policy entrepreneurs play strategically with the time and place of the policy process. In other words, they can strategically play with 
the policy arena, that is, the locus in which their policy game is placed and wherein problem definitions and policy ideas are turned into policy decisions (Timmermans and Bleiklie 1999). There are two different arena strategies, one focusing on place, and one focusing on time: the venue shopping and the timing strategy.

\section{Venue shopping}

Venue shopping is associated with the choice between the various possible places where one can effect change. By employing this strategy, policy entrepreneurs "try to alter the roster of participants who are involved in the issue by seeking out the most favorable venue for the consideration of their issues" (Baumgartner and Jones 1991:1045). At some points, policy entrepreneurs might prefer to act in accordance with regular and established procedures, whereas at other moments, or even in parallel, they might prefer a venue without the usual or prescribed procedures. Possible venues include not only different levels of government but also regulatory agencies and legislative bodies (McCown 2004). Especially in surroundings that provide little or no support for policy change, venue shopping can improve the policy entrepreneurs' chances for success and therefore lead to dramatic reversals in policy outcomes (Baumgartner and Jones 1991, Mintrom 2000). For this reason, and in accordance with Huitema and Meijerink (2010), we expected that venue shopping is an important strategy for policy entrepreneurs.

In our study, we found that most policy entrepreneurs noted that venue shopping can potentially result in new sets of participants involved in a particular policy issue and therefore may disarm opponents or strengthen the position of supporters of a particular policy change. Yet, contrary to our expectation, policy entrepreneurs most often experience very little freedom in the choice of possible places where they could effect change. In other words, it became clear that, at the subnational regional level, where concrete projects needs to be realized, the recognition, exploitation, and manipulation of different venues are only a strategy of minor importance. This is different from the national level (Meijerink and Huitema 2010). Presumably, this distinction can be explained by differences in institutional context, as the subnational regional level might offer less alternative venues than the national context. Only in terms of subsidy acquisitions, policy entrepreneurs in Dutch water management feel that venue shopping can be fruitful and enhance their chances of policy change.

\section{Timing}

A second arena strategy is timing. In a variety of ways, time plays an important role in policy making. Time is not only the outcome of a process; it has an independent influence on the process as well. Strategies to influence time differ in their extent. Kingdon (1984) notes that policy entrepreneurs should be alert to the right moments and refers to this chance for action as the opening of the policy window. Due to the short moments of opening windows, it is crucial for policy entrepreneurs to recognize and exploit those moments appropriately (Kingdon 1984, Huitema and Meijerink 2010). In anticipating the presence or absence of policy windows, policy entrepreneurs can try to speed up or slow down the policy-making process. Yet, as the sense of urgency and willingness to change perceptions will not continue indefinitely, focusing events can only create opportunities when the timing is right, and the moment in which ideas are presented and participants get involved is highly important (de Bruijn and ten Heuvelhof 2000), we expected that the timing strategy also functions as an overarching, or meta-, strategy.

The notion that timing is important is supported by our study. In line with Kingdon (1984) and Huitema and Meijerink (2010), we found that policy entrepreneurs in Dutch water management are always on the lookout for policy windows. Besides, policy entrepreneurs play for time by slowing down, requesting a time out, or asking for more research. Deadlines, on the other hand, are used to accelerate the process, even if policy entrepreneurs are aware that these effects are not always straightforward. In addition, the interviews revealed that policy entrepreneurs act strategically with deadlines initiated by other parties. One of them explained his reaction on a deadline set by the other party: "Since I am not in a hurry, setting a deadline would be really stupid. Whereas the other party feels the pressure, we won't negotiate until very close to the deadline ... this makes our position much stronger." More importantly, the policy entrepreneurs interviewed for this study regularly underlined the importance of timing in relation to the different attention- and support-seeking, linking, and relational management strategies, and herewith provide evidence for our assumption that timing functions also as a metastrategy. For example, and consistent with the suggestion of de Bruijn and ten Heuvelhof (2000), policy entrepreneurs feel that it is better to involve participants at an early stage to prevent resistance. At the same time, they indicated that engaging too early can be unfavorable. "It works counterproductive when you involve people too early. If you can only say 'there is something we want, but we do not know what and when', you only foster fantasies, ghosts, and stirs up trouble."

\section{DISCUSSION AND CONCLUSION}

This micro-level study on strategies of policy entrepreneurs working in regional project settings generated more in-depth knowledge and more detailed understanding of the variety and diversity of strategies that policy entrepreneurs employ. We found that, in their efforts to direct policy change, policy entrepreneurs in Dutch water management employ a wealth of strategies that can be grouped into attention- and supportseeking strategies, linking strategies, relational management strategies, and arena strategies. In this manner, our study 
contributed important new empirical and theoretical insights to explain policy change. This study complements the work of several other scholars who described the strategic behavior of policy entrepreneurs (e.g., King and Roberts 1987, Schneider et al. 1995, Mintrom and Vergari 1998, Mintrom 2000). It also complements the work of Robert and King (1991) and, more recently, Huitema and Meijerink (2009a, 2010), who offered a detailed description of entrepreneurial strategies, yet had a different focus. Huitema and Meijerink (2010) focused on policy transitions at the national level and based their theoretical analysis therefore primarily on the policy sciences literature. In this study, our focus is on the subnational level, where most practical projects are carried out. For this reason, we also extensively draw on the literature on project management and network management. Yet, overall, our findings support their earlier study. Also at the subnational regional level, policy entrepreneurs build coalitions and sell ideas, orchestrate and manage networks, and recognize and exploit windows of opportunity. Yet, unlike at the national level, the recognition, exploitation, and manipulation of different venues are much less important at the subnational level. Also, the first strategy identified by Huitema and Meijerink (2010) - the development of new ideas-is not identified as a separate strategy in this study.

Apart from the contributions on the strategies themselves, our comprehensive study in the Dutch water management sector generated several additional important findings. Policy entrepreneurs by no means employ the foregoing strategies in a chronological order. Instead, we found that policy entrepreneurs concurrently employ attention- and supportseeking strategies, linking strategies, relational management strategies, and arena strategies. Using Westley's (2002) conceptualization that envisions strategies as balls, one can conclude that, in order to be successful, policy entrepreneurs must constantly juggle all balls and cannot neglect or drop a single one. We concluded that policy entrepreneurs in their juggling efforts constantly focus on three strategic focal points. First, they use strategies to draw attention to new problems or to change existing problem definitions. Secondly, entrepreneurs use strategies to introduce (new) solutions or the perception of them. Thirdly, entrepreneurs use strategies to maintain or change the constitution of, or relation with, participants. Following the conceptualization of the stream models by Cohen et al. (1972) and Kingdon (1984), we can say that policy entrepreneurs pay close attention to three streams: the problem stream, the solution stream, and the participation stream. Interestingly, we found that most strategies are used to direct more than one stream. The strategy of rhetorical persuasion, for example, is used to influence the perception of the problem and the solution as well as to build trust and facilitate collaboration. But we found more interlinkages between the three streams and the strategies. For example, the problem definition itself, as well as the policy proposition, is affected by who is involved, just as the actors' decisions of whether or not to participate in a particular policy issue depends on the definition of the problem, the proposed solution, and the existing relationship. In addition, changes in the proposed solutions can affect existing problem definitions and vice versa. This leads us to the conclusion that, in contrast to Kingdon's argument, the streams affect each other as they develop.

What is more, whereas Kingdon (1984) assumes that developing and coupling of streams develops rather unpredictably and only when the "time is right," our study suggests that, by employing certain strategies, the development of streams and their coupling can to some extent also be influenced and steered. On the basis of what policy entrepreneurs put forward in our interviews, we conclude that, by operating strategically, policy entrepreneurs are indeed, to some degree, capable of directing policy change. This fairly optimistic finding is in contrast to what is suggested in many prevailing theories on policy change, in which it is commonly assumed that policy change is nearly impossible to realize without, for example, the occurrence of external shocks (Sabatier and Weible 2007) or punctuations (Baumgartner and Jones 1991). Yet, given the wide range of strategies that policy entrepreneurs use in Dutch water management, one may ask whether the conclusion would be justified that this steering and coupling is straightforward and unproblematic. The strategic dilemmas that this study has uncovered alone suggest that this is certainly not the case. Nevertheless, our findings are promising in the light of the fact that the capability to adapt to and to direct change is a key element of resilience in socialecological systems (Gunderson 1999, Folke et al. 2005). In connection with this, it is worth noting that policy entrepreneurs generally appear to be very good at making appraisals as to when to involve which actors. At times, policy entrepreneurs advocate broad coalitions or even processes of collaborative management, along the lines of adaptive comanagement (Olsson et al. 2007, Berkes 2009). Other times, they consciously avoid such processes, often because they fear complication and stagnation, from time to time also because they simply want their idea to be accepted. This latter finding corroborates the work of Meijerink and Huitema (2010). However, their conclusion that policy entrepreneurs thus "create barriers to future change" needs refining. Policy entrepreneurs in Dutch water management are constantly on the alert for future policy-change opportunities, and by no means do they only focus on one single transition. In fact, unlike the findings at the national level by Huitema and Meijerink (2010), we observed that, at a subnational regional level, policy entrepreneurs frequently employ strategies (in particular the game linking strategy), precisely for the reason that they are also involved in both concurrent and future policy-change trajectories. 
The above conclusions about policy entrepreneurs and policy change are important but need also to be approached with some caution, which points to further research needs. First, the number of interviewees in this study is relatively limited; for increased validity, future research should encompass a wider set of respondents. Second, it would be interesting to see to what extent, if at all, there are differences between the strategies of policy entrepreneurs and those of political and public entrepreneurs, which are not included in this study. A third limitation of this study is that we did not follow policychange projects in time but discussed processes retrospectively. To deepen our understanding of the success and appropriateness of distinct entrepreneurial strategies and to examine when strategies are combined with what effect, such an alternative approach would be recommended. Fourth, as to better understand to what extent the context in which this research was conducted might have influenced our resultsthat is, a small country marked by a dense and highly consensus-based policy network-future research needs to draw on an extended research design that includes international comparisons. After all, Te Boekhorst et al. (2010) have shown that policy entrepreneurs in a centralized country such as China have a rather different role and position as compared with those in European countries.

Responses to this article can be read online at:

http://www.ecologyandsociety.org/voll6/iss4/art5/responses/

\section{Acknowledgments:}

We are grateful to Michael Mintrom, Jeroen Warner, and Thijs Etty, and especially Dave Huitema, for inspiration and constructive discussions. The research described here has benefitted from financial contributions of the European Union (the Newater project, contract no. 511179 GOCE and the FP7 RESPSONSES project, Grant Agreement number 244092), and the Dutch knowledge impulse program Living with Water. We thank the anonymous reviewers for their valuable comments and suggestions.

\section{LITERATURE CITED}

Armitage, D., F. Berkes, and N. Doubleday. 2007. Introduction: moving beyond co-management. Pages 1-15 in D. Armitage, F. Berkes, and N. Doubleday, editors. Adaptive co-management: collaboration, learning, and multi-level governance. UBC Press, Vancouver, Canada.

Axelrod, R., and R. O. Keohane. 1985. Achieving cooperation under anarchy: strategies and institutions. World Politics 38 (1):226-254. http://dx.doi.org/10.2307/2010357

Baumgartner, F. R., and B. D. Jones. 1991. Agenda dynamics and policy subsystems. The Journal of Politics 53 (4):1044-1074. http://dx.doi.org/10.2307/2131866
Baumgartner, F. R., and B. D. Jones. 1993. Agendas and instability in American politics. University of Chicago Press, Chicago, Illinois, USA.

Berkes, F. 2009. Evolution of co-management: role of knowledge generation, bridging organizations and social learning. Journal of Environmental Management 90:1692-1702. http://dx.doi.org/10.1016/j.jenvman.2008.12.001

Biermann, F. 2007. "Earth system governance" as a crosscutting theme in global change research. Global Environmental Change: Human and Policy Dimensions 17 (3-4):326-337. http://dx.doi.org/10.1016/j.gloenvcha.2006.11.010

Biermann, F., and B. Siebenhüner, editors. 2009. Managers of global change: the influence of international environmental bureaucracies. MIT Press, Cambridge, Massachusetts, USA.

Birkland, T. A. 1988. Focusing events, mobilization, and agenda setting. Journal of Public Policy 18(1):53-74. http://d x.doi.org/10.1017/S0143814X98000038

Booher, D. E., and J. E. Innes. 2000. Network power in collaborative planning. Journal of Planning Education and Research 21(3):221-236. http://dx.doi.org/10.1177/0739456X $\underline{0202100301}$

Cohen, M. D., J. G. March, and J. P. Olsen. 1972. A garbage can model of organizational choice. Administrative Science Quarterly 17(1):1-25. http://dx.doi.org/10.2307/2392088

de Bruijn, J. A., and E. F. ten Heuvelhof. 2000. Networks and decision making. LEMMA, Utrecht, The Netherlands.

deLeon, L. 1996. Ethics and entrepreneurship. Policy Studies Journal 24:495-510. http://dx.doi.org/10.1111/j.1541-0072.1996. tb01642.x

Drucker, P. D. 1985. Innovation and entrepreneurship. HarperCollins, New York, New York, USA. http://dx.doi.org /10.1080/07377366.1986.10401060

Dutton, J. E., and S. J. Ashford. 1993. Selling issues to top management. The Academy of Management Review 18 (3):397-428. http://dx.doi.org/10.2307/258903

Fischhendler, I. 2004. Legal and institutional adaptation to climate uncertainty: a study of international rivers. Water Policy 6:281-302.

Fischhendler, I., and D. Zilberman. 2005. Packaging policies to reform the water sector: the case of the Central Valley Project Improvement Act. Water Resources Research 41:1-14. http://dx.doi.org/10.1029/2004WR003786

Fisher, R., W. Ury, B. Patton, and H. Kuipers. 1983. Excellent onderhandelen: een praktische gids voor het best mogelijke resultaat in iedere onderhandeling. Veen, Utrecht, The Netherlands. 
Folke, C., T. Hahn, P. Olsson, and J. Norberg. 2005. Adaptive governance of social-ecological systems. Annual Review of Environment and Resources 30(1):441-473. http://dx.doi.org/ 10.1146/annurev.energy.30.050504.144511

Gleick, P. H. 2003. Global freshwater resources: soft-path solutions for the 21st century. Science 302(5650):1524-1528. http://dx.doi.org/10.1126/science.1089967

Gunderson, L. H. 1999. Resilience, flexibility and adaptive management: antidotes for spurious certitude? Conservation Ecology 3(1):7. [online] URL: http://www.consecol.org/vol3/ iss $1 / \operatorname{art} 7 /$

Hahn, T., P. Olsson, C. Folke, and K. Johansson. 2006. Trustbuilding, knowledge generation and organizational innovations: the role of a bridging organization for adaptive comanagement of a wetland landscape around Kristianstad, Sweden. Human Ecology 34(4):573-592. http://dx.doi.org/10 $.1007 / \mathrm{s} 10745-006-9035-\mathrm{Z}$

Huitema, D., and S. Meijerink, editors. 2009a. Water policy entrepreneurs: a research companion to water transitions around the globe. Edward Elgar, Cheltenham, UK.

Huitema, D., and S. Meijerink. 2009b. Policy dynamics in Dutch water management: analyzing the contribution of policy entrepreneurs to policy change. Pages 349-368 in D. Huitema and S. Meijerink, editors. Water policy entrepreneurs: a research companion to water transitions around the globe. Edward Elgar, Cheltenham, UK.

Huitema, D., and S. Meijerink. 2010. Realizing water transitions: the role of policy entrepreneurs in water policy change. Ecology and Society 15(2): 26. [online] URL: http:// www.ecologyandsociety.org/vol15/iss $2 /$ art26/

Ingram, H., and L. Fraser. 2006. Path dependency and adroit innovation: the case of California water. Pages 78-109 in R. Repetto, editor. Punctuated-equilibrium and the dynamics of U.S. environmental policy. Yale University Press, New Haven, Connecticut, USA.

Innes, J. E., and D. E. Booher. 2010. Planning with complexity: an introduction to collaborative rationality for public policy. Routledge, London, UK.

Johnson, B. L. 1999. Introduction to the special feature: adaptive management - scientifically sound, socially challenged? Ecology and Society 3(1). [online] URL: http://W ww.ecologyandsociety.org/vol3/iss 1/art10/

King, P. J., and N. C. R. Roberts. 1987. Policy entrepreneurs: catalysts for policy innovation. Journal of State Government 60:172-179.

Kingdon, J. W. 1984. Agendas, alternatives, and public policies. HarperCollins, New York, New York, USA. http://d x.doi.org/10.3886/ICPSR28024
Koppenjan, J. 1993. Management van de beleidsvorming: een studie naar de totstandkoming van beleid op het terrein van het binnenlands bestuur. VUGA, 's-Gravenhage, The Netherlands.

Koppenjan, J., and E. H. Klijn. 2004. Managing uncertainties in networks: a network approach to problem solving and decision making. Routledge, London, UK.

Kuhnert, S. 2001. An evolutionary theory of collective action: Schumpeterian entrepreneurship for the common good. Constitutional Political Economy 12(1):13-29. http://dx.doi.o rg/10.1023/A:1016677020228

Kuks, S. M. M. 2010. Institutional evolution of the Dutch water board model. Pages 155-170 in S. Reinhard and H. Folmer, editors. Water policy in the Netherlands: integrated management in a densely populated delta. RRF Press, Washington, D.C., USA.

Lebel, L., P. Garden, and M. Imamura. 2005. The politics of scale, position, and place in the governance of water resources in the Mekong region. Ecology and Society 10(2): 18. [online] URL: http://www.ecologyandsociety.org/vol10/iss2/art18/

McCown, T. L. 2004. Policy entrepreneurs and policy change examining the linkages between TANF, domestic violence and the FVO. West Virginia University Libraries, Morgantown, West Virginia, USA.

Meijerink, S. 2008. Explaining continuity and change in international policies: issue linkage, venue change, and learning on policies for the river Scheldt estuary 1967-2005. Environment and Planning 40:848-866. http://dx.doi.org/10.1 $\underline{068 / \mathrm{a} 3911}$

Meijerink, S., and D. Huitema. 2010. Policy entrepreneurs and change strategies: lessons from sixteen case studies of water transitions around the globe. Ecology and Society 15(2): 21. [online] URL: http://www.ecologyandsociety.org/vol15/iss2/ art21/

Mintrom, M. 1997. Policy entrepreneurs and the diffusion of innovation. American Journal of Political Science 41 (3):738-770. http://dx.doi.org/10.2307/2111674

Mintrom, M. 2000. Policy entrepreneurs and school choice. Georgetown University Press, Washington, D.C., USA.

Mintrom, M., and S. Vergari. 1996. Advocacy coalitions, policy entrepreneurs, and policy change. Policy Studies Journal 24(3):420-434. http://dx.doi.org/10.1111/j.1541-007 2.1996.tb01638.x

Mintrom, M., and S. Vergari. 1998. Policy networks and innovation diffusion: the case of state education reforms. The Journal of Politics 60(1):126-148. http://dx.doi.org/10.2307/2 $\underline{648004}$ 
Mintzberg H., L. Jorgensen, D. Dougherty, and F. Westley. 1996. Some surprising things about collaboration: knowing how people connect makes it work better. Organizational Dynamics 25:60-71. http://dx.doi.org/10.1016/S0090-2616(96) $\underline{90041-8}$

Olsson, P., C. Folke, and F. Berkes. 2004. Adaptive comanagement for building resilience in social-ecological systems. Environmental Management 34(1):75-90. http://dx.d oi.org/10.1007/s00267-003-0101-7

Olsson, P., C. Folke, V. Galaz, T. Hahn, and L. Schultz. 2007. Enhancing the fit through adaptive co-management: creating and maintaining bridging functions for matching scales in the Kristianstads Vattenrike Biosphere Reserve Sweden. Ecology and Society 12(1): 28. [online] URL: http://www.ecologyand society.org/vol12/iss1/art28/

Olsson, P., L. H. Gunderson, S. R. Carpenter, P. Ryan, L. Lebel, C. Folke, and C. S. Holling. 2006. Shooting the rapids: navigating transitions to adaptive governance of socialecological systems. Ecology and Society 11(1): 18. [online] URL: http://www.ecologyandsociety.org/vol11/iss1/art18/

Ostrom, E. 1965. Public entrepreneurship: a case study in ground water basin management. Dissertation. Department of Political Science, University of California, Los Angeles, California, USA.

Pahl-Wostl, C., G. Berkamp, and K. Cross. 2006. Adaptive management of upland rivers facing global change: general insights and specific considerations for the Rhone Basin. [online] URL: http://rosenberg.ucanr.org/documents/Rosenbe rg_Paper_Pahl-Wostlcanada.pdf

Plummer, R., and D. R. Armitage. 2007. Charting the new territory of adaptive co-management: a Delphi study. Ecology and Society 12(2): 10. [online] URL: http://www.ecologyand society.org/vol12/iss $2 /$ art10/

Putnam, R. D. 1988. Diplomacy and domestic politics: the logic of two-level games. International Organization 42 (3):427-460. http://dx.doi.org/10.1017/S0020818300027697

Roberts, N. C., and P. J. King. 1991. Policy entrepreneurs: their activity structure and function in the policy process. Journal of Public Administration Research and Theory 2:147-175.

Roth D., and J. Warner. 2007. Flood risk, uncertainty and changing river protection policy in the Netherlands: the case of "calamity polders." Tijdschrift voor Economische en Sociale Geografie 98(4):519-525. http://dx.doi.org/10.1111/j $.1467-9663.2007 .00419 . \mathrm{x}$

Sabatier, P. A., and C. Weible. 2007. The advocacy coalition framework: innovations and clarifications. Pages 189-220 in
P. A. Sabatier, editor. Theories of the Policy Process. Westview Press, Boulder, Colorado, USA.

Schiller, W. 1995. Senators as policy entrepreneurs: using bill sponsorship to shape legislative agendas. American Political Science Review 39:186-203. http://dx.doi.org/10.2307/2111763

Schneider, M., P. E. Teske, and M. Mintrom. 1995. Public entrepreneurs: agents for change in American government. Princeton University Press, Princeton, New Jersey, USA.

Stevenson, H. H., and J. C. Jarillo. 1990. A paradigm of entrepreneurship: entrepreneurial management. Strategic Management Journal 11:17-27.

Stone, D. 1997. The art of political decision making. W. W. Norton, New York, New York, USA.

Te Boekhorst, D. G. J., T. J. M. Smits, X. Yu, L. Li, G. Lei, and C. Zhang. 2010. Implementing integrated river basin management in China. Ecology and Society 15(2): 23. [online] URL: http://www.ecologyandsociety.org/vol15/iss2/art23/

Teisman, G. R. 1990. Projectontwikkeling als "konzertierte aktion." Pages 207-208 in J. A. M. Hufen, and A. B. Ringeling, editors. Beleidsnetwerken: overheids-, semi-overheids-en particuliere organisaties in wisselwerking. VUGA, Den Haag, The Netherlands.

Timmermans, A., and I. Bleiklie. 1999. Institutional conditions for policy. Design: types of arenas and rules of the game. Paper presented to the ECPR Joint Sessions of Workshops, March 31, Mannheim, Germany.

Van der Brugge, R., J. Rotmans, and D. Loorbach. 2005. The transition in Dutch water management. Regional Environmental Change 5(4):164-176. http://dx.doi.org/10.1007/ s10113-004-0086-7

Van Leussen, W., and K. Lulofs. 2010. Governance of water resources. Pages 171-184 in S. Reinhard and H. Folmer, editors. Water policy in the Netherlands: integrated management in a densely populated delta. RRF Press, Washington, D.C., USA.

Walters, C., and C. S. Holling. 1990. Large-scale management experiments and learning by doing. Ecology 71(6):2060-2068. http://dx.doi.org/10.2307/1938620

Weissert, C. S. 1991. Policy entrepreneurs, policy opportunists, and legislative effectiveness. American Political Quarterly 19:262-274. http://dx.doi.org/10.1177/1532673X9 $\underline{101900207}$ 
Westley, F. 2002. The devil in the dynamics: adaptive management on the front lines. Pages 333-360 in L. H. Gunderson and C. S. Holling, editors. Panarchy: understanding transformations in human and natural systems. Island Press, Washington, D.C., USA.

Williams, P. 2002. The competent boundary spanner. Public Administration 80(1):103-124. http://dx.doi.org/10.1111/146 $\underline{7-9299.00296}$

Young, O. R. 1991. Political leadership and regime formation: on the development of institutions in international society. International Organization 45(3):281-308. http://dx.doi.org/1 $\underline{0.1017 / S 0020818300033117}$ 
APPENDIX 1. Sample of interview questions



Round 1: The first round of interviews was highly open and explorative and structured around two primary topics: the entrepreneurs' background, ambition, and work context, and the step-bystep description of the strategic decisions taken in the context of two highly innovative and complex projects they were involved with. The original questionnaire included 55 questions.

1. How would you describe the main goals of the project?

2. How would you describe the discussions in your internal organization at the start and during this project? How did you cope with these discussions?

3. In the course of the project, did partners join or drop out? Which? When? Why?

4. If at all, what was the influence of prior experiences with involved partners on the project?

5. If at all, what kind of problems did you encounter along the process? How were these problems solved?

6. Did you notice typical breakthroughs during the project? If so, when?

7. Did you foresee these breakthroughs? If so, how did you recognize them?

8. Is it possible to steer these breakthroughs? If so, how?

9. If at all, what dilemmas played a role during this project?

10. What choices did you make concerning these dilemmas? Why?

Round 2: In the second round, we confronted the same policy entrepreneurs with 20 statements on strategies and strategic dilemmas based on the results of the first "open" round. These statements are oversimplified by design; however, in the answers, we were most interested in the nuance.

1. I feel it is more strategic to link with other plans instead of initiating a new/personal plan.

2. Good relations are more important than fast goal achievement.

3. I prefer tough playing over conflict avoidance.

4. I involve other partners as soon as possible.

5. I prefer achieving goals now over achieving goals in the future. 